\title{
ANALISIS INTERCARRIER INTERFERENCE (ICI) PADA OFDM-MIMO BERDASARKAN M-ARY PHASE SHIFT KEYING (M-PSK)
}

\author{
Ni Made Arny Megasari ${ }^{1}$, I GAK Diafari Djuni ${ }^{2}$, Ni Made Ary Esta Dewi ${ }^{3}$ \\ Program Studi Teknik Elektro, Fakultas Teknik, Universitas Udayana \\ Email: arnymegasari96@gmail.com ${ }^{1}$, igakdiafari@unud.ac.id ${ }^{2}$, arydev02@yahoo.com ${ }^{3}$
}

\begin{abstract}
ABSTRAK
Salah satu teknik yang digunakan untuk mengatasi multipath fading adalah Ortoghonal Frequency Division Multiplexing (OFDM). Sistem OFDM adalah salah satu teknik multicarrier yang memiliki frekuensi orthogonal satu sama lain dengan menggunakan bandwidth yang sempit. Kelemahan sistem OFDM yang terjadi pada kanal mobile disebabkan variasi waktu pada kanal sehingga orthogonalitas pada subchannel akan hilang dan menimbulkan intercarrier interference (ICI). Penelitian ini bertujuan untuk menganalisis intercarrier interference (ICI) pada sistem OFDM MIMO dengan menggunakan modulasi BPSK dan QPSK pada kanal fading, ditinjau dari nilai dan grafik Bit Error Rate (BER) berbanding dengan Energy Bit per Noise (Eb/No). Penelitian ini juga bertujuan untuk mengetahui pengaruh frequency offset pada system OFDM-MIMO. Hasil perbandingan sistem OFDM-MIMO dengan nilai frekuensi offset yang berbeda yaitu 2, 4, dan $6 \mathrm{kHz}$, menghasilkan frequency offset $2 \mathrm{kHz}$ paling baik. Pada perhitungan Eb/NO $5 \mathrm{~dB}$ pada modulasi BPSK dengan nilai frekuensi offset $2 \mathrm{kHz}$ mendapatkan nilai BER 0.0037, untuk nilai frekuensi offset $4 \mathrm{kHz}$ di modulasi BPSK mendapatkan nilai BER 0.0058 dan untuk nilai frekuensi offset $6 \mathrm{kHz}$ pada modulasi BPSK mendapatkan nilai BER sebesar 0.0114 .
\end{abstract}

Kata Kunci:BPSK, intercarrier interference (ICI), MIMO, OFDM, QPSK

\begin{abstract}
One of the techniques that are used to define the multipath fading it can make is Ortoghonal Frequency Division Multiplexing (OFDM). System on multicarrier technique is one that has a frequency of orthogonal to each other by using a narrow bandwidth. The weakness of the system on which occurred in mobile channel due to the technique of the time on a channel so that orthogonalitas on a subchannel would pose intercarrier interference and missing (ICI). This research aims to analyze the intercarrier interference (ICI) on the system on MIMO using BPSK and QPSK modulation in fading channel. In terms of values and graph of Bit Error Rate $(B E R)$ is proportional to the energy per Bit to noise (Eb/no). This research also aims to find out the influence of frequency on the system on-MIMO offset. The results of the comparison of the system of on-frequency offset value with MIMO that applies fruit 2, 4 and $6 \mathrm{kHz}$, a frequency of $2 \mathrm{kHz}$ offset produces the most good. On the calculation of the $5 \mathrm{~Eb} N \mathrm{NO}$ BPSK modulation with $d B$ on the value of the offset frequency of $2 \mathrm{kHz}$ getting the value of the Bit Error Rate 0.0037, for the value of the frequency offset $4 \mathrm{kHz}$ in modulation BPSK BER 0.0058 and get value for value frequency offset of $6 \mathrm{kHz}$ on modulation BPSK get the value of the BER of 0.0114 .
\end{abstract}

Keywords: BPSK, intercarrier interference (ICI), MIMO, OFDM, QPSK

\section{PENDAHULUAN}

Perkembangan teknologi komunikasi wireless saat ini mengaharuskan akses yang berkecepatan tinggi dengan kualitas sinyal yang baik serta tahan terhadap gangguan dan interferensi. Gangguan yang terjadi pada komunikasi wireless adalah multipath fading. Multipath fading mengakibatkan sinyal yang diterima oleh receiver tidak sama dengan sinyal yang dikirim oleh transmitter. Teknik untuk mengatasi multipath fading adalah 
Ortoghonal Frequency Division Multiplexing (OFDM). Sistem OFDM adalah teknik multicarrier yang memiliki frekuensi orthogonal satu sama lain dengan menggunakan bandwidth yang sempit [1]. Fungsi sistem OFDM adalah membagi-bagi data yang memiliki bandwidth tinggi menjadi deretan data rate paralel yang memiliki bandwidth yang lebih rendah. Kelemahan pada sistem OFDM yang terjadi pada kanal yang bergerak dikarenakan variasi waktu pada kanal sehingga orthogonalitas pada subchannel akan hilang dan menimbulkan intercarrier interference (ICI) [2]. Frequency offset akan menyebabkan terjadinya intercarrier interference $(\mathrm{ICl})$ dan menurunkan kinerja dari sistem.

Teknik modulasi yang diterapkan kepada sinyal yang telah termodulasi, sebagai modulasi tingkat kedua dengan menggunakan Orthogonal Frequency Divisio Multiplexing (OFDM). Caranya yaitu dengan membagi data secara paralel pada sejumlah subkanal pita sempit, masingmasing data pada subkanal dimodulasikan dengan subfrekuensi receiver yang saling orthogonal, selanjutnya data ditransmisikan secara bergilir, OFDM ini mampu mengirimkan aliran data dengan kecepatan tinggi. Dengan cara membaginya ke dalam aliran-aliran data berkecepatan rendah. Proses yang dilakukan dengan teknik modulasi multicarrier, yang membedakan adalah penggunaan sub pembawa yang saling othogonal pada masing-masing subkanal.

Modulasi merupakan teknik pemetaan (mapping) untuk memodulasi data atau bit sinyal informasi yang masuk.Teknik modulasi yang digunakan yaitu BPSK, QPSK yang akan mengolahnya menjadi bitbit informasi dan diproses ke dalam kanal AWGN dan kanal fading[3]. Pada penelitian ini penulis akan mengamati penyebab terjadinya Intercarrier Interference agar mengetahui bagaimana performansi dari system OFDM-MIMO dengan menggunakan modulasi $m$-ary phase shift keying (M-PSK) pada kanal AWGN dan fading dengan menggunakan MIMO STBC2x2. Penelitian tentang STBC sudah dilakukan pada D-MIMO dengan menggunakan teknik waterfilling [4]. Sehingga pada penelitian ini menerapkan teknik MIMO STBC2x2 tersebut diharapkan mampu untuk mengetahui penyebab terjadinya ICI pada kanal mobile [2].

\section{KAJIAN PUSTAKA}

\subsection{Orthogonal Frequency Division Multiplexing}

Orthogonal Frequency Division Multiplexing (OFDM) merupakan suatu teknik transmisi yang menggunakan banyak frekuensi yang saling tegak lurus (orthogonal). Sistem OFDM dapat membuat frekuensi setiap subcarrrier saling orthogonal satu sama lain dimana setiap frekuensi saling overlap tanpa rentan terhadap ISI dengan cara menambahkan guard interval pada setiap frekuensi subcarrier [3]. Model spektrum subcarrier tidak overlap dan overlap orthogonal ditunjukkan pada gambar 1.

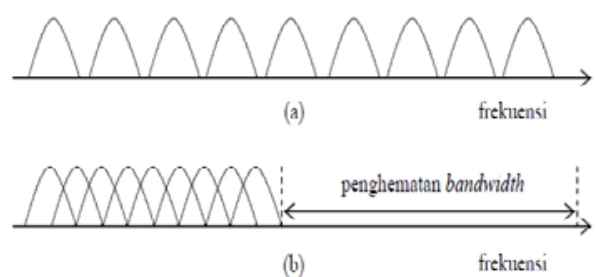

Gambar 1 Model spektrum subcarrrier (a) tidak overlap (b) overlap orthogonal

Dengan sifat orthogonalitas ini maka antar subcarrier dapat dibuat overlap tanpa menimbulkan efek Inter Carrier Interference (ICl). Dengan multiplexing subcarrier yang dilakukan secara overlap tersebut tentu saja dapat menghemat bandwidth. Proses yang dilakukan sama dengan teknik modulasi multicarrier, yang membedakan hanya pada penggunaan subcarrier yang saling orthogonal pada masing-masing subkanal

\subsection{Intercarrier Interfernce (ICl)}

Intercarrier Interference terjadi pada subkanal yang digunakan oleh subkanal yang berada pada blok data yang sama dari pengguna yang sama. Jika hanya terdapat satu pengguna dalam komunikasi OFDM, ICl juga mungkin terjadi. Faktor yang menyebabkan $\mathrm{ICl}$ adalah frekuensi offset dan time variant.

\subsection{Carrier Frequency Offset (CFO)}

Pada receiver sinkronisasi sebelum mendemodulasikan sub-carrier, yaitu memperkirakan dan memperbaiki offset frekuensi carrier atau Carrier Frequency 
Offset (CFO) sinyal yang diterima yang dapat menyebabkan ICI [3]. Gambar 2 menunjukkan frequency offset pada sinyal.
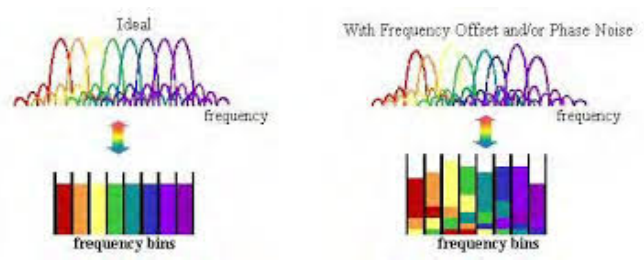

Gambar 2 Frequency offset pada sinyal [4]

\subsection{Multiple Input Multiple Output}

Sistem MIMO adalah sistem yang menggunakan dua antena baik pada pengirim maupun penerima untuk mengatasi kekurangan pada sistem komunikasi wireless. Kekurangan diantaranya adalah large scale fading, small scale fading termasuk didalamnya multipath fading serta interference dari sinyal lain. Sistem MIMO memberikan penambahan efisiensi spektral yang didasarkan pada penggunaan space diversity pada transmitter dan receiver [1]. Gambar 3 menunjukkan sistem MIMO.

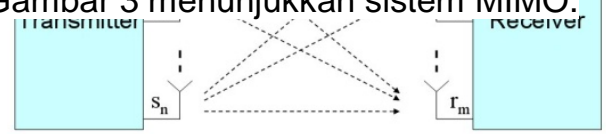

\section{Gambar 3 Sistem MIMO [1]}

\subsection{Sistem Space Time Block Code (STBC)}

STBC adalah skema yang digunakan dalam teknik transmit diversity untuk mencapai diversity gain pada sistem MIMO [3]. Pada sistem STBC yang digunakan Alamouti, aliran data yang sama dipancarkan melalui kedua antena pemancar. Sebelum dipancarkan, aliran data terlebih dahulu mendapatkan perlakuan yang berbeda. Pengiriman setiap dua simbol akan tetap dikirimkan dua periode, namun pada antena kedua urutan simbolnya dibalik, dikonjugasi, dan salah satunya dinegatifkan. Tujuan dari cara tersebut adalah untuk memudahkan pemisahan kedua simbol pada sisi penerima sehingga deteksi dua simbol dapat dipecah menjadi dua proses deteksi simbol yang terpisah.

\subsection{Modulasi BPSK}

Pada Binary Phase Shift Keying (BPSK), phasa dari frekuensi sinyal pembawa diubah-ubah dengan dua nilai yang menyatakan keadaan biner 1 dan 0 . Dalam BPSK phasa dari frekuensi pembawa yang satu dengan yang lain berbeda sebesar $180^{\circ}$. Diagram konstelasi BPSK ditunjukkan pada gambar 4.

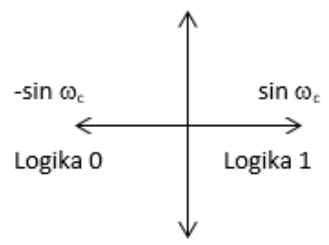

Gambar 4 Diagram konstelasi BPSK [6]

\subsection{Modulasi QPSK}

Pada Quardrature Phase Shift Keying (QPSK) sinyal informasi dibawa dalam bentuk phasa yang berbeda. Istilah "quadrature" mengartikan terdapat 4 phasa (4-PSK) yang dimiliki oleh sinyal pembawa pada satu waktu. Modulasi QPSK memiliki empat buah bentuk sinyal yang merepresentasikan empat kode binary, yaitu '00', '01', '11', '10' yang dinamakan bit dimana setiap bit membangkitkan satu dari kemungkinan phasa [6]. Diagram konstelasi QPSK ditunjukkan pada gambar 5.

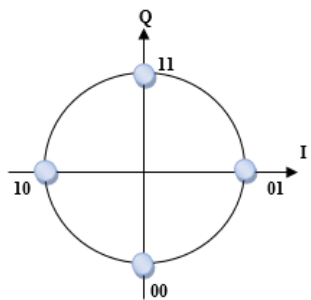

Gambar 5 Diagram konstelasi QPSK [6]

\section{METODOLOGI PENELITIAN}

Diagram alir diperlukan untuk membantu poses pembuatan sistem. Mulai dari study literature, perancangan perangkat keras, perancangan perangkat lunak, dan terakhir adalah proses pengujian dari alat yang telah dibuat. Pada gambar 6 dapat dilihat Diagram alir keseluruhan dari sistem OFDM-MIMO. Gambar 6 menunjukan diagram alur analisis penelitian umum. 


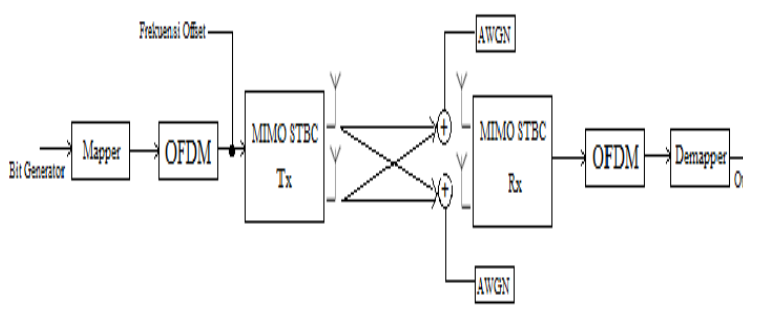

Gambar 6 Diagram Alur Analisis Penelitian

\section{Umum}

\section{HASIL DAN PEMBAHASAN}

\subsection{Hasil}

Hasil dari penelitian unjuk kerja mengenai pengaruh frequency offset terhadap Inter-Carrier Interference (ICI) pada sistem OFDM-MIMO. Dimana pada setiap sub bab akan ditampilkan beberapa hasil perbandingan dari uji coba sesuai dengan kajian teoritis yang dikemukakan pada kajian pustaka. Akan ditampilkan gambar grafik yang akan menunjukkan hasil dari percobaan tersebut. Parameter yang digunakan dalam simulasi sistem OFDM dapat dilihat pada tabel 1.

Tabel 1 Parameter Simulasi [2]

\begin{tabular}{|c|c|}
\hline Parameter & $\begin{array}{l}\text { Nilai yang } \\
\text { digunakan }\end{array}$ \\
\hline $\begin{array}{l}\text { Ukuran/ panjang simbol } \\
\text { OFDM (L) }\end{array}$ & 64 \\
\hline $\begin{array}{l}\text { Number of used } \\
\text { subcarriers. nDSC }\end{array}$ & 52 \\
\hline Jumlah simbol FFT & 64 \\
\hline Tipe modulasi & $\begin{array}{c}\text { BPSK, QPSK, 8- } \\
\text { PSK, 16-PSK }\end{array}$ \\
\hline $\begin{array}{l}\text { FFT Sampling } \\
\text { Frequency }\end{array}$ & $20 \mathrm{Mhz}$ \\
\hline Subcarrier spacing & $312.5 \mathrm{kHz}$ \\
\hline Used subcarrier index & $\{-26$ to $-1,+1$ to +26$\}$ \\
\hline Periode FFT & $3.2 \mu \mathrm{s}$ \\
\hline Periode cyclic prefix & $0.8 \mu \mathrm{s}$ \\
\hline Periode Simbol Total & $4 \mu \mathrm{s}$ \\
\hline
\end{tabular}

A. Hasil Perbandingan Sistem OFDM MIMO yang tidak mengalami Frequency Offset dengan Sistem OFDM MIMO yang mengalami Frequency Offset.

Gambar 7 dan 8 adalah grafik perbandingan BER vs EB/NO mengenai perbandingan system OFDM-MIMO yang mengalami frequency offset $2 \mathrm{kHz}$ dengan menggunakan modulasi BPSK. Parameter yang digunakan mengacu pada tabel 1 dengan menggunakan bit inputan $10^{6}$, dimana sumbu y pada grafik adalah Bit Error Rate (BER) sedangkan sumbu $x$ adalah Eb/NO.

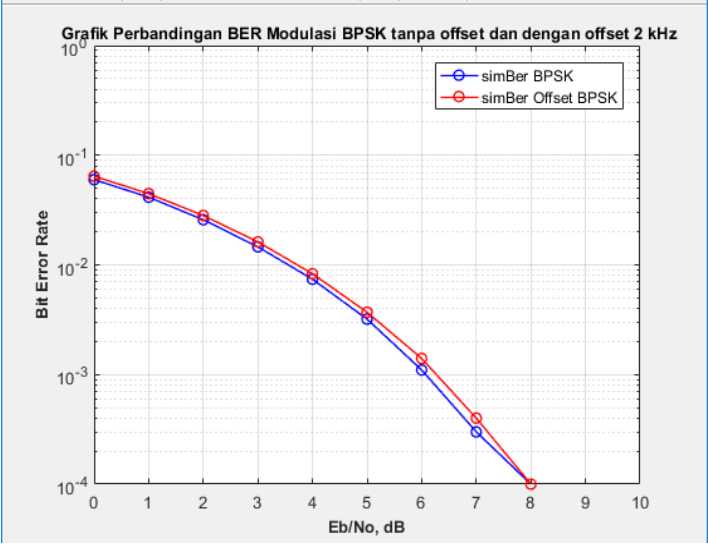

Gambar 7 Perbandingan perbandingan sistem OFDM-MIMO yang tidak mengalami frequency offset dengan sistem OFDM MIMO yang mengalami frequency offset.

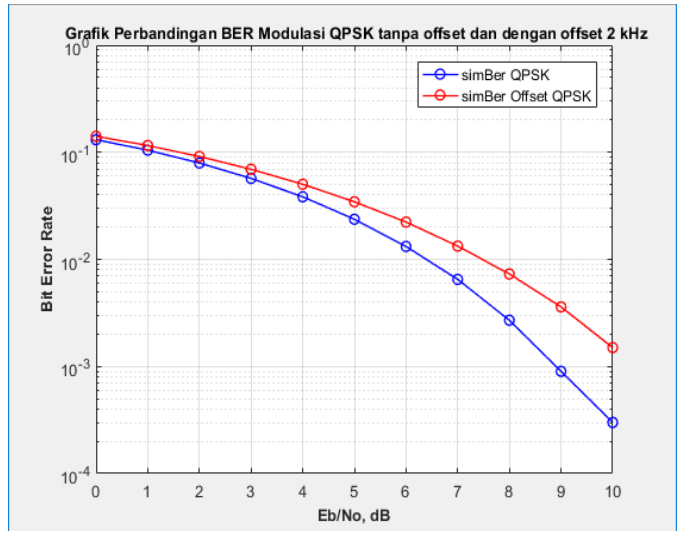

Gambar 8 Perbandingan perbandingan sistem OFDM-MIMO yang tidak mengalami frequency offset dengan sistem OFDM MIMO yang mengalami frequency offset.

B. Grafik Perbandingan Unjuk Kerja Sistem OFDM MIMO dengan Frequency Offset yang Bervariasi

Gambar 9 dan 10 adalah grafik perbandingan BER vs EB/NO mengenai perbandingan system OFDM-MIMO yang mengalami frequency offset 2,4,6 $\mathrm{kHz}$ dengan menggunakan modulasi BPSK dan QPSK. Parameter yang digunakan mengacu pada tabel 1 dengan 
menggunakan bit inputan $10^{6}$, dimana sumbu y pada grafik adalah Bit Error Rate (BER) sedangkan sumbu $x$ adalah Eb/NO.

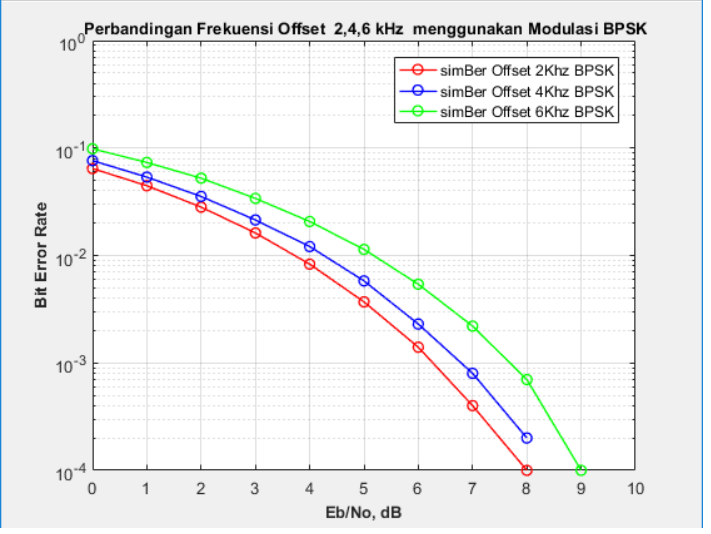

Gambar 9 Perbandingan Sistem OFDM MIMO Frequency Offset dengan nilai yang bervariasi menggunakan Modulasi BPSK.

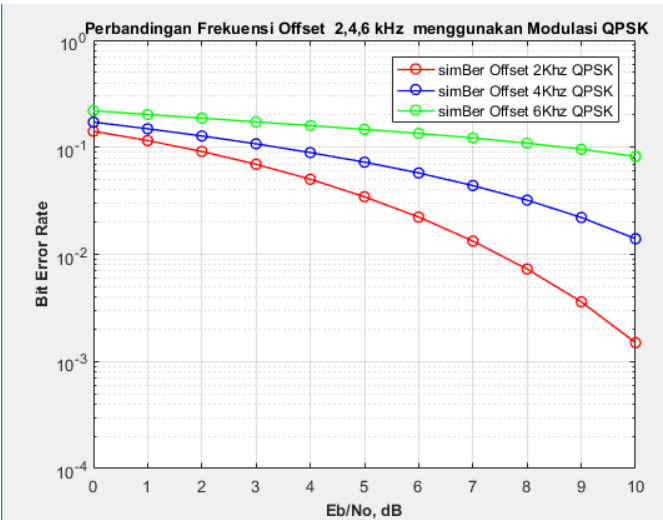

Gambar 10 Perbandingan Sistem OFDM MIMO Frequency Offset dengan nilai dengan nilai yang bervariasi menggunakan Modulasi QPSK.

C. Grafik Perbandingan Unjuk Kerja Sistem OFDM-MIMO Pada Modulasi yang Berbeda

Gambar 11,12 dan 13 adalah grafik perbandingan BER vs EB/NO mengenai perbandingan system OFDM-MIMO yang mengalami frequency offset $2 \mathrm{kHz}$ dengan menggunakan modulasi BPSK dan QPSK. Parameter yang digunakan mengacu pada tabel 1 dengan menggunakan bit inputan $10^{6}$, dimana sumbu y pada grafik adalah Bit Error Rate (BER) sedangkan sumbu $x$ adalah Eb/NO.

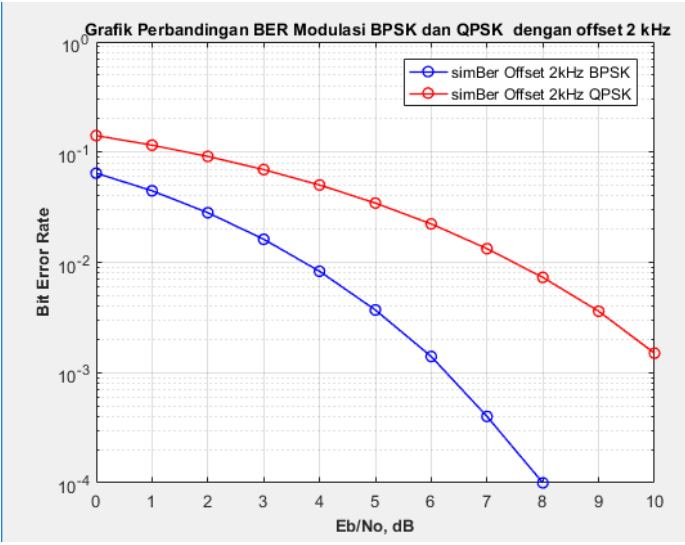

Gambar 11 Grafik BER vs Eb/NO dengan Frequency Offset $2 \mathrm{kHz}$

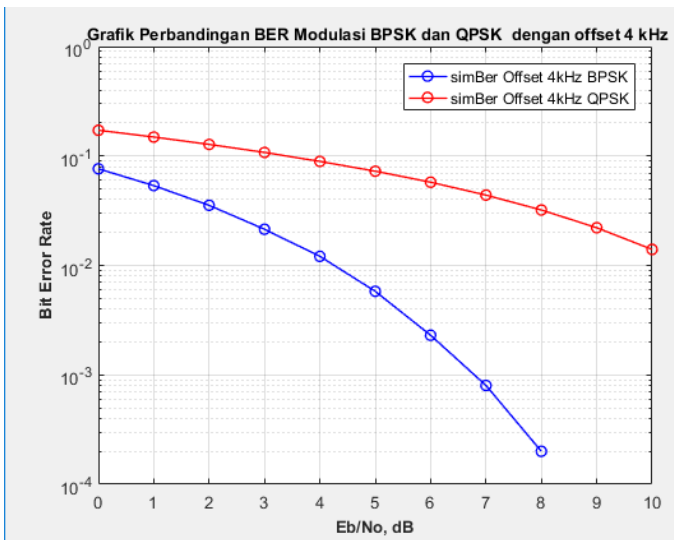

Gambar 12 Grafik BER vs Eb/NO dengan Frequency Offset $4 \mathrm{kHz}$

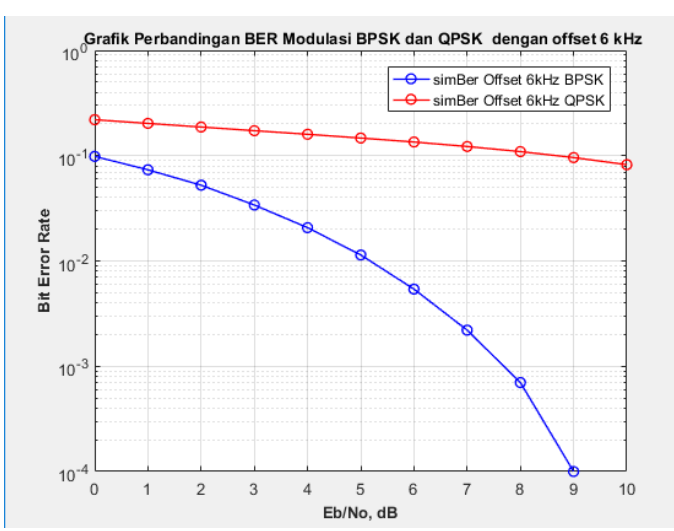

Gambar 13 Grafik BER vs Eb/NO dengan

\subsection{Pembahasan}

$$
\text { Frequency Offset } 6 \mathrm{kHz}
$$

Hasil dari penelitian unjuk kerja mengenai pengaruh frequency offset terhadap Intercarrier Interference (ICI) pada sistem OFDM-MIMO. Dimana pada setiap sub bab akan ditampilkan beberapa hasil perbandingan dari uji coba sesuai dengan kajian teoritis yang dikemukakan pada kajian pustaka. Akan ditampilkan gambar grafik yang akan menunjukkan hasil dari 
percobaan tersebut. Parameter yang digunakan dalam simulasi sistem OFDM dapat dilihat pada tabel 1 .

A. Perbandingan Sistem OFDM MIMO yang tidak mengalami Frequency Offset dengan Sistem OFDM MIMO yang mengalami Frequency Offset.

Pada Gambar 14 dan 15 garis yang berwarna biru sistem OFDM-MIMO yang tidak mengalami frequency offset, dan yang berwarna merah dengan sistem yang mengalami frequency offset $2 \mathrm{kHz}$. Sistem yang tidak mengalami frequency offset mendapatkan hasil lebih kecil dibandingkan sistem dengan sistem yang mengalami frequency offset $2 \mathrm{kHz}$.

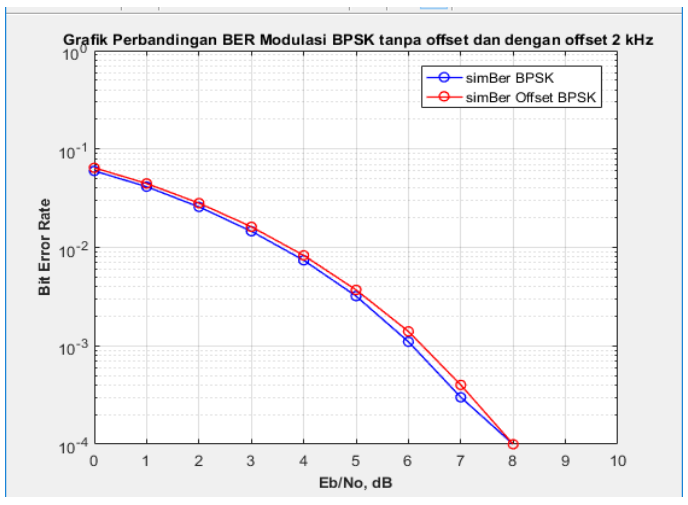

Gambar 14 Perbandingan Grafik sistem OFDM-MIMO yang tidak mengalami frequency offset dengan sistem OFDM MIMO yang mengalami frequency offset menggunakan modulasi BPSK.

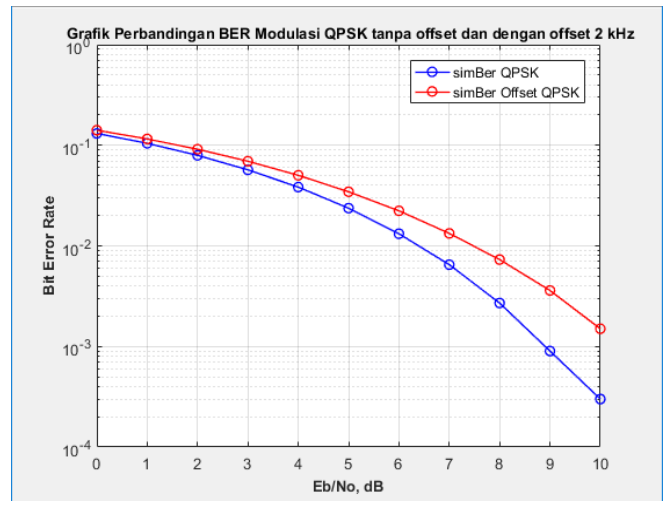

Gambar 15 Perbandingan Grafik sistem OFDM-MIMO yang tidak mengalami frequency offset dengan sistem OFDM MIMO yang mengalami frequency offset menggunakan modulasi QPSK.

Berdasarkan pada Gambar 7 dan 8, diantara sistem yang menggunakan frequency offset dan sistem yang tidak menggunakan frequency offset, maka sistem tanpa frequency offset memiliki nilai BER lebih rendah dikarenakan carrier pada transmitter dan pada receiver tidak mengalami overlapping pada subcarrier satu dengan yang lainnya. Sedangkan carrier transmiter dan carrier receiver pada sistem OFDM MIMO dengan frequency offset $2 \mathrm{kHz}$ mengalami ketidaksesuaian. Hal ini dikarenakan, frequency offset mengakibatkan antena pemancar ataupun antena penerima mengalami pergeseran frekuensi, sehingga frekuensi antara keduanya menjadi tidak sama. Apabila frekuensi antara antena pemancar dan antena penerima maka dapat mengganggu orthogonalitas carrier, maka akan menyebabkan adanya intercarrier interference yang sering disebut juga dengan $\mathrm{ICl}$.

B. Perbandingan Unjuk Kerja Sistem OFDM MIMO dengan Frequency Offset yang Bervariasi.

Pada Gambar 16 dan 17 garis yang berwarna merah sistem OFDM-MIMO yang mengalami frequency offset sebesar $2 \mathrm{kHz}$, yang berwarna biru dengan sistem yang mengalami frequency offset $4 \mathrm{kHz}$, dan yang berwarna hijau dengan sistem yang mengalami frequency offset $6 \mathrm{kHz}$. Sistem yang mengalami frequency offset sebesar 2 $\mathrm{kHz}$ mendapatkan hasil lebih kecil dibandingkan sistem dengan sistem yang mengalami frequency offset $6 \mathrm{kHz}$.

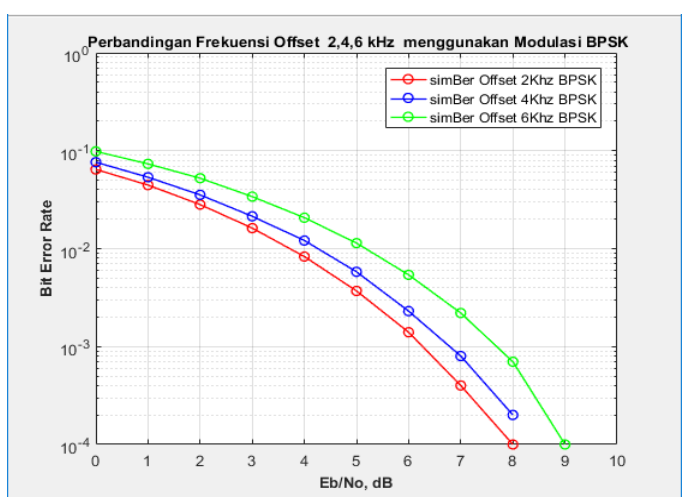

Gambar 16 Perbandingan Sistem OFDM MIMO Frekuensi Offset dengan nilai yang bervariasi menggunakan Modulasi BPSK. 


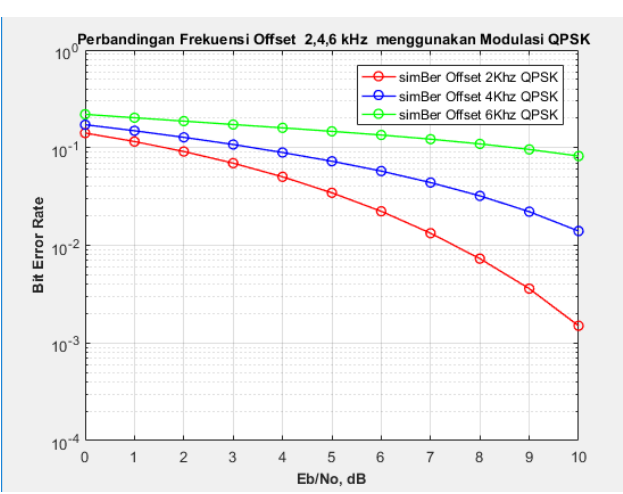

Gambar 17 Perbandingan Sistem OFDM MIMO Frekuensi Offset dengan nilai yang bervariasi menggunakan Modulasi QPSK.

Berdasarkan pada Gambar 9 dan 10 tersebut dengan normalisasi carrier frequency offset (CFO) yang berbeda pada setiap percobaan dapat dilihat pengaruh normalisasi carrier frequency offset (CFO) terhadap inter-carrier interference (ICI), semakin besar normalisasi carrier frekuensi offset (CFO) maka semakin sempit spasi antar sub-carrier, sehingga perbandingan antara frekuensi maksimum dengan spasi frekuensi antara sub-carrier semakin besar, jadi semakin besar pula interferensi antar sub-carrier atau inter-carrier interference (ICl).

Sistem yang memiliki nilai frekuensi offset lebih rendah akan mendapatkan hasil lebih baik daripada sistem yang memiliki nilai lebih tinggi karena akibat dari tidak sesuai (mismatch) antara osilator pemancar dan osilator penerima. Sehingga semakin besar Eb/NO akan berpengaruh pada nilai BER yang semakin mengecil.

C. Perbandingan Unjuk Kerja Sistem OFDM-MIMO Pada Modulasi yang Berbeda

Pada Gambar 18, 19 dan 20 garis yang berwarna biru sistem OFDM-MIMO yang menggunakan modulasi BPSK, yang berwarna biru dengan sistem yang menggunakan modulasi QPSK. Sistem yang menggunakan modulasi BPSK lebih baik dibandingkan yang menggunakan QPSK.

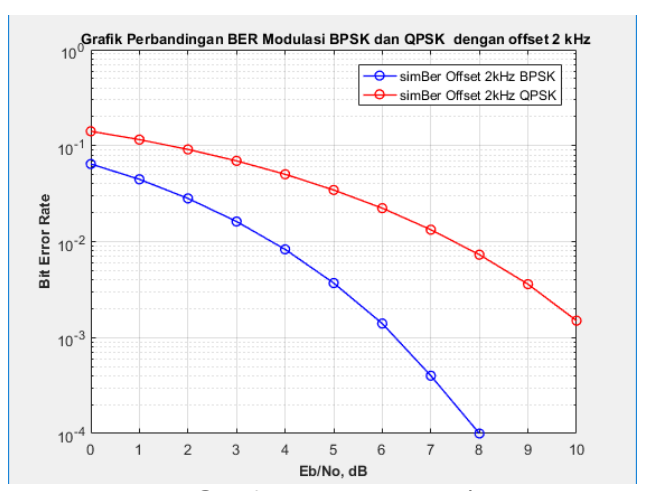

Gambar 18 Grafik BER vs Eb/NO dengan Frequency Offset $2 \mathrm{kHz}$

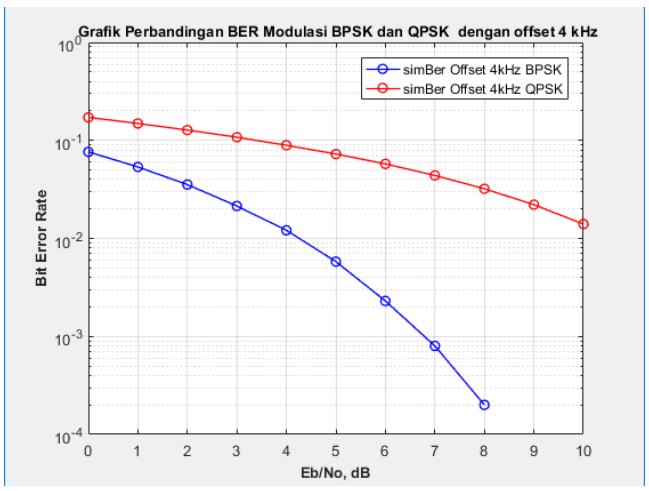

Gambar 19 Grafik BER vs Eb/NO dengan Frequency Offset $4 \mathrm{kHz}$

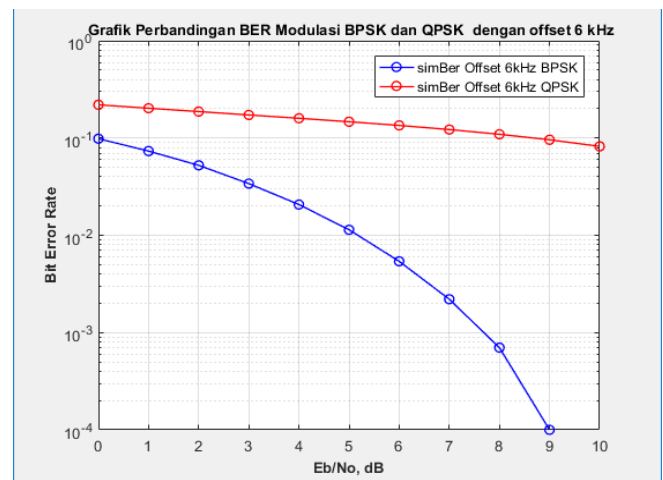

Gambar 20 Grafik BER vs Eb/NO dengan Frequency Offset $6 \mathrm{kHz}$

Pada modulasi BPSK memiliki nilai BER yang lebih rendah dibandingkan kanal modulasi QPSK. Dikarenakan untuk fase modulasi BPSK range yang digunakan $180^{\circ}$ setiap satu bit sedangkan untuk fase pada mosulasi QPSK range yang digunakan yaitu $90^{\circ}$ mewakili dua bit.

\section{Simpulan}

Simpulan dari penelitian ini adalah sebagai berikut: 
1. Performansi sistem OFDM-MIMO yang tidak mengalami frequency offset lebih baik dibandingkan dengan sistem OFDM-MIMO yang mengalami frequency offset $2 \mathrm{kHz}$ pada kanal fading menggunakan modulasi BPSK dan QPSK. BER modulasi BPSK yang tidak mengalami frequency offset dan dengan sistem yang mengalami frequencyoffset $2 \mathrm{kHz}$ dengan nilai Eb/NO $5 \mathrm{~dB}$ yang tidak mengalami frequencyoffset mendapatkan nilai BER 0.0032 sedangkan pada modulasi BPSK yang mengalami frequencyoffset $2 \mathrm{kHz}$ mendapatkan nilai BER 0.0037 .

2. Hasil perbandingan sistem OFDMMIMO dengan nilai frequency offset yang berbeda yaitu 2, 4, dan $6 \mathrm{kHz}$, mengahasilkan frequency offset $2 \mathrm{kHz}$ paling baik. Pada perhitungan Eb/NO 5 $\mathrm{dB}$ pada modulasi BPSK dengan nilai frekuensi offset $2 \mathrm{kHz}$ mendapatkan nilai BER 0.0037, untuk nilai frequency offset $4 \mathrm{kHz}$ di modulasi BPSK mendapatkan nilai BER 0.0058 dan untuk nilai frequency offset $6 \mathrm{kHz}$ pada modulasi BPSK mendapatkan nilai BER sebesar 0.0114 .

3. Hasil perbandingan unjuk kerja sistem OFDM-MIMO pada modulasi yang berbeda yaitu performansi pada sistem modulasi BPSK lebih baik dibandingkan QPSK. Pada perhitungan Eb/NO $5 \mathrm{~dB}$ pada modulasi BPSK dengan nilai frekuensi offset $2 \mathrm{kHz}$ mendapatkan nilai BER 0.0037 sedangkan di modulasi QPSK mendapatkan nilai 0.0345 , untuk nilai frequency offset $4 \mathrm{kHz}$ di modulasi BPSK mendapatkan nilai BER 0.0058 sedangkan pada modulasi QPSK mendapatkan nilai 0.0726 dan untuk nilai frequency offset $6 \mathrm{kHz}$ pada modulasi BPSK mendapatkan nilai BER sebesar 0.0114 sedangkan pada modulasi QPSK mendapatkan nilai 0.0237. Dikarenakan untuk fase modulasi BPSK range yang digunakan $180^{\circ}$ setiap satu bit sedangkan untuk fase pada mosulasi QPSK range yang digunakan yaitu $90^{\circ}$ mewakili dua bit.

\section{DAFTAR PUSTAKA}

[1] Irhamsyah. "MIMO OFDM untuk
Komunikasi WLAN dengan
Pengkodean Space Time Block
Code (STBC)", Program Studi Teknik Elektro Program Pascasarjana Bidang Ilmu Teknik Universitas Indonesia; 2008. http://lib.ui.ac.id/file?file=digital /117108-T\%2024706Mimo\%20OFDM-HA.pdf, diakses 5 Desember 2017).

[2] Septi,Wike. "Pengaruh Modulasi M-PSK pada Unjuk Kerja Sistem Orthogonal Frequency Division Multiplexing (OFDM)". Fakultas Teknik Universitas Diponegoro; 2011. https://www.researchgate.net/ publication/279664124 PENGARUH MODULASI M-

PSK PADA UNJUK KERJA SIST EM ORTHOGONAL FREQUENCY DIVISION MULTIPLEXING OFDM , diakses 5 Desember 2017.

[3] Johan. "Perbandingan Bitrate antara OFDM-TDMA dengan OFDMA pada Teknologi Wimax". Fakultas Teknik Universitas Sumatera Utara Medan; 2008.https://anzdoc.com/universitasindonesia-simulasi-dan-analisismimo-ofdma-pada-.html, diakses 5 Desember 2017.

[4] Gunantara, N, "Analisis Unjuk Kerja Teknik Pengkodean STBC dan Waterfilling Pada Sistem D-MIMO". Majalah IImiah Teknik Elektro, vol. 7, no. 2, July - December 2008.

[5] Puspito,S.W.J, "Mengenal Teknologi Orthogonal Frequency Division Multiplexing (OFDM) pada Komunikasi Wireless". Jurnal Elektro Indonesia, Nomor 24, Tahun V. http://journal.unas.ac.id/giga/articl e/view/293, diakses 5 Desember 2017).

[6] Faisal, Muhammad, "Pengaruh Panjang Cyclic Prefix Terhadap Kinerja Sistem OFDM". 2016. https://www.researchgate.net /publication/42353354 Pengaruh P anjang Cyclic Prefix Terhadap Ki neria Sistem OFDM Pada WiMax , diakses 7 Desember 2017.

[7] Hakim, M. Lukmanul, Sukiswo, Santoso Imam, "Analisis Kinerja Sistem MIMO OFDM Pada Kanal Rayleigh dan AWGN dengan Modulasi QPSK". Universitas Diponegoro;2008. https://ejournal.u ndip.ac.id/index.php/transmisi/articl 
